\title{
Studies on neuropharmacological and analgesic effects of Periploca aphylla extract in mice
}

\author{
Abdul Jabbar ${ }^{1}$, Shafi Muhammad ${ }^{1 *}$, Ghulam Razaque ${ }^{2}$, Abdul Qadir ${ }^{2}$, \\ Mohammad Younis ${ }^{3}$, Nisar Ahmad ${ }^{4}$, Iftikhar Baloch ${ }^{5}$ and Ghulam \\ Mustafa $^{2}$ \\ 1. Department of Pharmacognosy, Faculty of Pharmacy and Health Sciences, University of Balochistan, Quetta- \\ Pakistan \\ 2. Department of Pharmaceutics, Faculty of Pharmacy and Health Sciences, University of Balochistan, Quetta- \\ Pakistan \\ 3. Department of Pharmacology, Faculty of Pharmacy and Health Sciences, University of Balochistan, Quetta- \\ Pakistan \\ 4. Department of Pharmaceutical Chemistry, Faculty of Pharmacy and Health Sciences, University of Balochistan, \\ Quetta-Pakistan \\ 5. Department of Botany, University of Balochistan, Quetta-Pakistan \\ *Corresponding author's email: Pharmacognosist59@yahoo.com
}

Citation

Abdul Jabbar, Shafi Muhammad, Ghulam Razaque, Abdul Qadir, Muhammad Younis, Nisar Ahmad, Iftikhar Baloch and Ghulam Mustafa. Studies on neuropharmacological and analgesic effects of Periploca aphylla extract in mice. Pure and Applied Biology. Vol. 5, Issue 4, pp1207-1215. http://dx.doi.org/10.19045/bspab.2016.50145

\begin{tabular}{llll}
\hline \hline Received: 20/10/2016 & Revised: 28/10/2016 & Accepted: 31/10/2016 & Online First: 04/11/2016 \\
\hline
\end{tabular}

\section{Abstract}

The current study was carried out on a crude extract of stem of Periploca aphylla. It is found in the regions of Jhal magsi, Khuzdar and Pujgur in Balochisatn. P. aphylla has numerous therapeutic uses in traditional medicine. It is used for the relief of pain, ulcer, skin disorders, tumors and for extensive range of other diseases. In neuropharmacological studies mice treated with the crude extract of $P$. aphylla showed sedative effects in open field, cage crossing, traction and rearing test particularly at the dose of $500 \mathrm{mg} / \mathrm{kg}$ as compared with standard drug diazepam. In force induced swiming test increase in immobility time was observed at the dose of 250 and $500 \mathrm{mg} / \mathrm{kg}$. Results were significantly comparable with standard drug diazepam. The administration of the crude extract of $P$. aphylla produced significant analgesic effects particularly at the dose of $500 \mathrm{mg} / \mathrm{kg}$ in the acetic acid induced writhing test and the formalin test. In conclusion, results suggests that the methanolic extract of $P$. aphylla possesses sedative effects and potent analgesic effects.

keywords: Analgesic; Periploca aphylla; Sedative

\section{Introduction}

Plants are vital components of healthy life since they deliver us food and medicines that are safe and effective. Medicinal plants play an important role due to the presence of wide variety of bioactive compounds in them and having various biological and pharmacological activities [1]. About 6000 medicinal plant species exist in Pakistan, and Balochistan which is the largest 
province of Pakistan, has many medicinal plants [2]. Periploca aphylla is a medicinal plant of Balochistan and is used by the local people to cure various diseases. It is found in the regions of Jhal Magsi, Pujgur and Khuzdar in Balochistan [3].

$P$. aphylla belongs to the genus Periploca (Asclepiadaceae), which has twelve species. In Pakistan three species have been found. Genus Periploca is medicinally very important [4]. P. aphylla is called as "Bata" or "Barara." Locally. Part used is milky juice from the stem and is used for swellings and tumors. It is also employed to treat flu, cough, and swollen joints. P. aphylla is also used for the treatment of constipation, ulcer and skin diseases. Numerous chemical compounds isolated from P.aphylla have shown antibacterial activities and $\alpha$ glucosidase (type VI) inhibitory effect $[5,6]$. Studies on phytochemical constituents of $P$. aphylla show the occurrence of steroids [7], flavonoids, terpenoids, cardiac glycoside, tannins, betacyanin, coumarin and amino acids. Current research work was carried out to explore the effect of $P$. aphylla on central nervous system (CNS) and its ability to inhibit the pain as previously no data was available on nueropharmacological and analgesic activities of the plant.

\section{Material and methods}

\section{Plant material}

Plant material (stem) was collected from Jhal magsi District of Balochistan, Pakistan. Plant was identified by Mrs. Bushra Aziz Khan, Assistant Professor, Department of Pharmacognosy, Faculty of Pharmacy and Health Sciences, University of Balochistan. Voucher specimen No. J-213 was submitted in herbarium of Pharmacognosy department. Plant material was dried under shade and soaked in methanol for 15 days under reduced pressure by using rotary evaporator. After evaporation of solvent, dark green residue was obtained.

\section{Animals}

Male and female (both) albino mice, weighing about 20-25 gram were collected from the CASVAB (Centre of advance studies in vaccinology and biotechnology) University of Balochistan, Quetta. Animals were kept under standard environments, temperature was maintained at $25 \pm 1{ }^{\circ} \mathrm{C}$, in 12 hours light/ 12 hours dark cycle. The animals had free access to water and feed. Prior to experimentation, the animals were adjusted to Lab environment for 7 days.

\section{Phytochemical tests}

Phytochemical tests were carried out for the presence of Alkaloids, Terpenoids, Saponins, Glycosides, Tannins and Flavonoids [8].

\section{Neuropharmacological studies}

Neuropharmacological studies were carried out by Open field activity, cage crossing activity, rearing activity, traction test and forced swimming test on mice. Mice were divided in 4 groups, Group $\mathrm{A}=$ Control (Distilled water treated), Group $\mathrm{B}=$ Crude extract $250 \mathrm{mg} / \mathrm{Kg}$ treated group, Group $\mathrm{C}=$ crude extract $500 \mathrm{mg} / \mathrm{Kg}$ treated group and Group $\mathrm{D}=$ Standard drug Diazepam treated group. Each group consisted of 5 mice.

\section{Open field activity}

The total area of apparatus was $76 \times 76 \mathrm{~cm}^{2}$, and the height of the walls was $42 \mathrm{~cm}$. Floor of apparatus was separated by means of lines into twenty five equal squares. Mice were placed in center of the apparatus (one at a time). Observation was to count (for 10 minutes) the number of squares crossed by the mice with four paws. Open field activities of control group, crude drug treated group and standard drug treated group were observed in balanced design to avoid order effect $[2,9]$.

\section{Rearing test}

Rearing test was conducted by using 1000 $\mathrm{ml}$ beaker. Bottom was covered with white paper. Animals were observed for 10 minutes [2, 9] for the count of upward 
movements during their erect position [10, 12].

\section{Cage crossing test}

Cage crossing test was carried out by using transparent plastic cage (26x 26 x26 cm). Mice were placed in the cages and number of cage crossings were noted for 10 minutes [13].

\section{Forced swimming test.}

Forced swimming test (FST) was used to determine the antidepressant activity [13, 14]. Test was conducted by placing the mice individually in a cylindrical tank $(18.5 \mathrm{~cm}$ height, $12.5 \mathrm{~cm}$ diameter) containing clean water at $25^{\circ} \mathrm{C}(13.5 \mathrm{~cm}$ depth $)$. Swimming was noted when horizontal and large movements of forepaws were made, that lead to dislocation of the mice body around the apparatus. After six minutes, mice were taken out of the apparatus and permitted to dry beneath a lamp and returned back to the home cage $[15,16]$.

\section{Traction test}

Traction test describes the sedative or stimulant activity of the drug. In this test the observation was to determine the time consumed by mice to travel an iron rod (of one-meter length). Before experiment, mice were trained to walk on the iron rod. Any decrease or increase in time taken by the mice were recorded and compared with control and standard drug treated animals [9, $10,17]$.

\section{Analgesic activity Acetic acid induced writhing test}

In this test abdominal constriction was induced in mice (weighing about 25-28 g). Acetic acid (0.6\% in $0.9 \%$ saline) $0.1 \mathrm{ml} / 10 \mathrm{~g}$ was administered I/P after 30 minutes of test drug administration. Control animals received $2 \mathrm{ml}$ of Distilled water and positive control received standard analgesic drug Aspirin $(300 \mathrm{mg} / \mathrm{kg}$ ). Total numbers of abdominal constrictions were counted for 30 minutes [18].

\section{Formalin test}

Twenty microliter of $2.5 \%$ formalin, made in distil water, was injected beneath surface of the right hind paw of the mice. Observation (number and time spent on licking and biting) was made for 30 minutes. In first phase (neurogenic pain), mice were observed from 0 to 5 minutes. In second phase mice were observed form 15-30 minutes [18].

\section{Statistical analysis}

All the calculations were recorded as mean with \pm SEM. The Dunnett's test was used to determine the significance of difference between the means and values of $\mathrm{P}<0.01$ were considered as highly significant and $\mathrm{P}<0.05$ significant [2].

\section{Results}

\section{Phytochemical tests}

Results were positive for the presence of tannins, terpenoids, saponins and flavonoids in phytochemical tests (Table 1).

Table 1. Preliminary phytochemical test of methanolic extract of $P$. aphylla

\begin{tabular}{|l|l|}
\hline Chemical Constituents & Stem extract of $\boldsymbol{P}$. aphylla \\
\hline Alkaloids & Absent \\
\hline Terpenoids & Present \\
\hline Saponins & Present \\
\hline Gglycosides & Absent \\
\hline Tannins & Present \\
\hline Flavonoids & Present \\
\hline
\end{tabular}

\section{Open filed activity}

For control group, squares crossed by the mice was $191.6 \pm 3.18$ taken as mean, and
$142 \pm 2.12$ and $134.6 \pm 2.5$ for $250 \mathrm{mg} / \mathrm{kg}$ and $500 \mathrm{mg} / \mathrm{kg}$ of mice treated with crude extract of $P$. aphylla respectively and $94.4 \pm 1.57$ for 
diazepam. Crude extract of $P$. aphylla field activity (Table 2). significantly $(\mathrm{p}<0.05)$ decreased the open

Table 2. Assessment open field activity

\begin{tabular}{|l|c|c|}
\hline Treatment & Dose $\mathbf{~ m g} / \mathbf{k g}$ orally & $\begin{array}{c}\text { Mean No. of observations } \\
\mathbf{\pm} \text { S.E.M }\end{array}$ \\
\hline Control & $0.5 \mathrm{ml}$ Distilled water & $191.6 \pm 3.18$ \\
\hline $\begin{array}{l}\text { Crude extract of } \\
\text { aphylla }\end{array}$ & $250 \mathrm{mg} / \mathrm{kg}$ & $142 \pm 2.12^{*}$ \\
\hline Diazepam & $500 \mathrm{mg} / \mathrm{kg}$ & $134.6 \pm 2.5^{*}$ \\
\cline { 2 - 3 } & $2 \mathrm{mg} / \mathrm{kg}$ & $94.4 \pm 1.57^{* *}$ \\
\hline
\end{tabular}

Values are the mean number of open field activities in 10 minutes. All values are mean \pm SEM; $\mathrm{n}=5 ; *=$ Significant results $(P<0.05), * *=$ highly significant results $(P<0.01)$

\section{Cage crossing test}

Cage crossing test showed increased depressant activity $(\mathrm{p}<0.05)$ at oral dose of $500 \mathrm{mg} / \mathrm{kg} P$. aphylla as compared with the Diazepam $2 \mathrm{mg} / \mathrm{kg}$ that produced $22.8 \pm 0.8$ number of cage crossing activities. At
$250 \mathrm{mg} / \mathrm{kg}$ and $500 \mathrm{mg} / \mathrm{kg}$ of crude extract $P$. aphylla, the average number of cage crossing activities were $35.4 \pm 1.5$ and $29.4 \pm$ 0.92 respectively. Whereas the average number of cage crossing activities for the control group were $48.2 \pm 0.86$ (Table 3 ).

Table 3. Assessment of cage crossing activity

\begin{tabular}{|l|c|c|}
\hline Treatment & Dose $\mathbf{~ m g} / \mathrm{kg}$ orally & $\begin{array}{c}\text { Mean No. of observations } \\
\mathbf{+} \text { S.E.M }\end{array}$ \\
\hline Control & $0.5 \mathrm{ml}$ Distilled water & $48.2 \pm 0.86$ \\
\hline Crude extract of & $250 \mathrm{mg} / \mathrm{kg}$ & $35.4 \pm 1.5^{*}$ \\
\hline Diazhylla & $500 \mathrm{mg} / \mathrm{kg}$ & $29.4 \pm 0.92^{*}$ \\
\cline { 2 - 3 } & $2 \mathrm{mg} / \mathrm{kg}$ & $22.8 \pm 0.8^{* *}$ \\
\hline
\end{tabular}

Values are the mean number of cage crossing activities in 10 minutes. All values are mean $\pm \mathrm{SEM} ; \mathrm{n}=5 ; *=$ Significant results $(P<0.05), * *=$ highly significant results $(P<0.01)$

\section{Rearing test}

In rearing test a reduction was seen in exploratory activity as well as in open field activity. The results show that rearing activity was depressed significantly $(\mathrm{p}<0.05)$ at the higher doses of the drug i-e $500 \mathrm{mg} / \mathrm{kg}$. Diazepam $2 \mathrm{mg} / \mathrm{kg}$ produced an average of $14.1 \pm 0.85$ rearing activities. On the contrary, when the oral dose of $P$. aphylla was administered at $250 \mathrm{mg} / \mathrm{kg}$ and $500 \mathrm{mg} / \mathrm{kg}$, the average number of rearing activities were $28.6 \pm 1.03$ and $23.4 \pm 0.81$ respectively. Whereas the average number of rearing activities for the control group was 39.4 \pm 0.92 (Table 4).

Table 4. Assessment of rearing activity

\begin{tabular}{|l|c|c|}
\hline Treatment & Dose mg/kg orally & $\begin{array}{c}\text { Mean No. of observations } \\
\mathbf{+ S . E . M}\end{array}$ \\
\hline Control & $0.5 \mathrm{ml}$ Distilled water & $39.4 \pm 0.92$ \\
\hline Crude extract of & $250 \mathrm{mg} / \mathrm{kg}$ & $28.6 \pm 1.03^{*}$ \\
\hline Diazhylla & $500 \mathrm{mg} / \mathrm{kg}$ & $23.4 \pm 0.81^{*}$ \\
\cline { 2 - 3 } & $2 \mathrm{mg} / \mathrm{kg}$ & $14.1+0.85 * *$ \\
\hline
\end{tabular}

Values are the mean number of rearing activities in 10 minutes. All values are mean $\pm \mathrm{SEM} ; \mathrm{n}=5$; * $=$ Significant results $(P<0.05),{ }^{* *}=$ highly significant results $(P<0.01)$ 


\section{Traction test}

In traction test it was observed that, when the oral dose of $500 \mathrm{mg} / \mathrm{kg}$ was given, the time to travel on iron rod was decreased. Average 11.2 0.37 seconds were taken by control group to travel the iron rod. When the dose of 250 and $500 \mathrm{mg} / \mathrm{kg}$ crude extract of $P$. aphylla was given, the average time taken to travel the iron rod by mice was 13.4 \pm 0.68 and $14.8 \pm 1.39$ seconds respectively. While it was $19.4 \pm 0.92$ seconds when the mice were treated with standard drug Diazepam (Table 5).

Table 5. Assessment of traction test

\begin{tabular}{|c|c|c|}
\hline Treatment & Dose $\mathrm{mg} / \mathrm{kg}$ orally & $\begin{array}{c}\text { Mean No. of observations } \\
\pm \text { S.E.M }\end{array}$ \\
\hline Control & $0.5 \mathrm{ml}$ Distilled water & $1 \overline{1} .2 \pm 0.37$ \\
\hline \multirow{2}{*}{$\begin{array}{l}\text { Crude extract of } \\
P \text {. aphylla }\end{array}$} & $250 \mathrm{mg} / \mathrm{kg}$ & $13.4 \pm 0.68 *$ \\
\hline & $500 \mathrm{mg} / \mathrm{kg}$ & $14.8 \pm 1.39 *$ \\
\hline Diazepam & $2 \mathrm{mg} / \mathrm{kg}$ & $19.4 \pm 0.92 * *$ \\
\hline
\end{tabular}

Values represent the mean \pm SEM. Statistically significant from control and standard drug. * Significant at $\mathrm{p}<0.05$, ** highly significant at $\mathrm{p}<0.005$.

\section{Forced swimming test}

The results of forced swimming test show that the mean mobility time of control (Distilled water treated) animals was 3.54+ 0.01 minutes and immobility time was $2.06 \pm$ 0.01 minutes, For mice treated with crude extract of $P$. aphylla at $250 \mathrm{mg} / \mathrm{kg}$ oral dose mobility time was $2.56 \pm 0.004$, immobility time was $3.04 \pm 0.01$ minutes. For mice treated with $500 \mathrm{mg} / \mathrm{kg}$ oral dose mobility time was $2.25 \pm 0.004$ and immobility time was $3.35 \pm 0.005$ minutes. For standard drug treated group, at the dose of $2 \mathrm{mg} / \mathrm{kg}$ the mobility time was $1.29 \pm 0.001$ and immobility time was $4.31 \pm 0.005$. The crude extract shows significant $(\mathrm{p}<0.05)$ results as compare to standard drug. Findings indicate that the crude extract of $P$. aphylla possesses both sedative and muscle relaxant activities (Table 6).

Table 6. Effect of crude extract of $P$. aphylla on forced swimming test in mice

\begin{tabular}{|l|l|l|l|}
\hline Treatment & Dose $\mathbf{~ m g / k g}$ orally & $\begin{array}{l}\text { Mobility time } \\
\text { Mean No. of } \\
\text { observations } \pm \text { +S.E.M }\end{array}$ & $\begin{array}{l}\text { Immobility time } \\
\text { Mean No. of } \\
\text { observations } \\
\mathbf{\pm} \text { S.E.M }\end{array}$ \\
\hline Control & $0.5 \mathrm{ml}$ Distilled water & $3.54 \pm 0.01$ & $2.06 \pm 0.01$ \\
\hline $\begin{array}{l}\text { Crude extract of } \text { aphylla } \\
\text { Diazepam }\end{array}$ & $300 \mathrm{mg} / \mathrm{kg}$ & $2.56 \pm 0.004^{*}$ & $3.04 \pm 0.01^{*}$ \\
\cline { 2 - 4 } & $500 \mathrm{mg} / \mathrm{kg}$ & $2.25 \pm 0.004^{*}$ & $3.35 \pm 0.02^{*}$ \\
\hline
\end{tabular}

All values are mean \pm SEM; $\mathrm{n}=5 ; *=$ Significant results $(P<0.05), * *=$ highly significant results $(P<0.01)$

\section{Analgesic activity}

Acetic acid induced writhing test

In this test aspirin $(300 \mathrm{mg} / \mathrm{kg})$ oral dose was used as reference drug. Significant $(\mathrm{p}<0.05)$ dose related inhibition of writhes were observed after administration of crude extract of P. aphylla (Table 7). 
Table 7. Effect of methanolic extract of $P$. aphylla on acetic acid induced writhing test in mice

\begin{tabular}{|l|c|c|}
\hline Treatment & Dose $\mathbf{~ m g} / \mathrm{kg}$ orally & $\begin{array}{c}\text { Mean No. of observations } \\
\text { +S.E.M }\end{array}$ \\
\hline Control & $0.5 \mathrm{ml}$ Distilled water & $84.2 \pm 0.37$ \\
\hline Crude extract of & $250 \mathrm{mg} / \mathrm{kg}$ & $54.6 \pm 1.5$ \\
\hline Asphylla & $500 \mathrm{mg} / \mathrm{kg}$ & $43.2 \pm 0.86$ \\
\cline { 2 - 3 } & $300 \mathrm{mg} / \mathrm{kg}$ & $35.6 \pm 1.03$ \\
\hline
\end{tabular}

Value represent the mean \pm SEM. Statistically significant from control and standard drug. * Significant at $\mathrm{p}<0.05$,

** highly significant at $\mathrm{p}<0.005$

\section{Formalin test}

In this test $P$. aphylla crude extract showed significant $(\mathrm{p}<0.05)$ analgesic effect (as decrease in number of licking and biting and time spent on licking and biting were observed). Results were more significant at $500 \mathrm{mg} / \mathrm{kg}$ oral dose as compared with aspirin (Table 8).

Table 8. Effect of crude extract of $P$. aphylla formalin induced inflammatory pain in mice

\begin{tabular}{|l|l|l|l|l|l|}
\hline Treatment & $\begin{array}{l}\text { Dose mg/kg } \\
\text { orally }\end{array}$ & \multicolumn{3}{|l|}{$\begin{array}{l}\text { First Phase } \\
\text { Mean No. of observations - } \\
\text { +S.E.M }\end{array}$} & $\begin{array}{l}\text { Second Phase } \\
\text { Mean No. of observations - } \\
\text { +S.E.M }\end{array}$ \\
\cline { 2 - 6 } & $\begin{array}{l}\text { Number of } \\
\text { Licking \& } \\
\text { Biting }\end{array}$ & $\begin{array}{l}\text { Time Spent } \\
\text { (Seconds) }\end{array}$ & $\begin{array}{l}\text { Number of } \\
\text { Licking \& } \\
\text { Biting }\end{array}$ & $\begin{array}{l}\text { Time Spent } \\
\text { (Seconds) }\end{array}$ \\
\hline Control & $\begin{array}{l}0.5 \mathrm{ml} \mathrm{Distilled} \\
\text { water }\end{array}$ & $60.4 \pm 2.20$ & $80.8 \pm 1.72$ & $76.2 \pm 1.99$ & $185.2 \pm 1.28$ \\
\hline $\begin{array}{l}\text { Crude } \\
\text { extract of } \\
P . \text { aphylla }\end{array}$ & $250 \mathrm{mg} / \mathrm{kg}$ & $43.4 \pm 0.81^{*}$ & $64.1 \pm 2.89^{*}$ & $67.6 \pm 1.16^{*}$ & $110.8 \pm 2.91^{*}$ \\
\cline { 2 - 6 } & $500 \mathrm{mg} / \mathrm{kg}$ & $33.8 \pm 1.65^{*}$ & $40.8 \pm 5.25^{*}$ & $43.8 \pm 1.24^{*}$ & $74.2 \pm 1.11^{*}$ \\
\hline Aspirin & $300 \mathrm{mg} / \mathrm{kg}$ & $23.8 \pm 1.59^{* *}$ & $34.8 \pm 1.16^{* *}$ & $25.4 \pm 1.21^{* *}$ & $40.8 \pm 2.27^{* *}$ \\
\hline
\end{tabular}

All values are mean \pm SEM; $\mathrm{n}=5 ; *=$ Significant results $(P<0.05),{ }^{*} *$ highly significant results $(P<0.01)$

\section{Discussions}

There was a positive evidence of presence of tannins and terpenoids as the phytochemical tests were carried out. Along with tannins and terpenoids, saponins and flavonoids were also present. As for as the results of neuropharmacological activities are concerned, rearing, cage crossing, open field and traction test showed significant decreased $\quad(\mathrm{p}<0.05)$ values which is indicative of the sedative and passive activity of the extract. The results were more significant at $500 \mathrm{mg} / \mathrm{kg}$ oral dose of $P$. aphylla. Alertness is suggestive of increase in loco-motor activity whereas sedation shows decrease in loco-motor activity [19,
21]. Depressed loco-motor activity of crude extract of the plant shows CNS depressant activity. Gamma-aminobutyric acid (GABA) is considered as inhibitory neurotransmitter in central nervous system. Most of the muscle relaxant, sedative and hypnotic drugs exert their action through this neurotransmitter. So it has been postulated that crude extracts of the $P$. aphylla may increase the inhibitory effect of this neurotransmitter by initiating membrane hyperpolarization which afterwards decrease the rate of firing of critical neurons in CNS. Another hypothesis about the above mentioned phenomena is that the plant extract directly activates the Gama 
aminobutyric acid receptors in the central nervous systems [20, 22, 23]. Tannins and flavonoids were also detected in phytochemical test. It has been seen that the plants containing saponins, flavonoids and tannins are useful for treating mental ailments [23, 24]. Extensive research has shown that there are certain flavonoids and neuroactive steroids that basically function as ligands for the gamma aminobutyric acid receptors in the central nervous system. Therefore, it is obviously understandable that these can act like Benzodiazepines [20, 23].

In animal models, for assessment of antidepressant activity, forced swimming test is applied. In such models anti-depressant activity is calculated by shortening of immobility time. On the other hand, if immobility duration is long, it reflects the depressant activity of the plant extract [21, 25]. Crude extract of the plant showed a marked central nervous system depressant activity which was dose dependent, and it may linked to the presence of flavonoids [25].

When acetic acid was administered intraperitoneally, it caused pain by abdominal muscle contraction which progressed into hind limb extension and body part elongation. All these effects are mediated by receptor located in peritoneum, [27] it is clear that the sensation of pain was produced by the intra peritoneal injection of acetic acid which causes the release of endogenous substances supposed to initiate the pain sensation. Prostaglandin E2, Prostaglandin F2 $\alpha$, Prostaglandin I2, certain other prostaglandins and peritoneal mast cells have accumulated due to this process which have shown by many studies [27] in peritoneal fluids treated with acetic acid. Capillary permeability is another mechanism by which acetic acid further increases the pain sensation [20].
Crude extracts of $P$. aphylla has the ability to reduce the writhing in mice induced by acetic acid. This is indicative of the fact that the plant possesses the anti-nociceptive activity [28].

There are two distinct phases in Formalin test which reflect different stages in the process of pain. The first phase shows its direct effect on nociceptors which are mainly responsible for non-inflammatory pain. Contrary to this, the second phase exerts its effect on inflammatory pain [29]. A significant $(\mathrm{P}<0.05)$ analgesic effect was produced in both phases. This indicates that the anti-nociceptive effect of the extract was produced by both inflammatory and neurogenic mechanisms [30].

\section{Conclusion}

Current study reveals that crude extracts of $P$. aphylla possess CNS depressant and analgesic activity. It may be used as alternative medicine for depression and as analgesic agent, however detail studies are required for isolation of active constituents responsible for its pharmacological effect.

\section{Authors' contributions}

Conceived and designed the experiments: S Muhammad \& G Razaque, Performed the experiments: A Jabbar \& $M$ Younis, Analyzed the data: A Qadir, Contributed reagents/materials/analysis tools: $\mathrm{N}$ Ahmad \& IA Baloch, Wrote the paper: A Jabbar \& G Mustafa.

\section{References}

1.Ajaib M, Khan ZU, Khan NA \& Wahab M (2010). Ethnobotanical studies on useful shrubs of district Kotli, Azad Jammu \& Kashmir,Pakistan. Pak J Bot 42(3): 1407-1415.

2.Ahmad M, Muhammed S, Mehjabeen, Jahan N, Jan SU \& Qureshi ZU (2014). Anti-dermatitis, anxiolytic and analgesic effects of Rhazya stricta from Balochistan. Pak J Pharm Sci 27(3): 481-486 
3.Khan MS \& Irshad SM (2005). A revised working list of the flowering plants of Balochistan. pp.158.

4.Umehara K, Sumii N, Satoh H, Miyase T, Kuroyanagi M \& Ueno A (1995). Studies on differentiation inducers. V. Steroid glycosides from periplocae radicis cortex. Chem Pharm Bull 43(9): 1565-1568.

5.Iqbal J, Zaib S, Farooq U, Khan A, Bibi I \& Suleman S (2012). Antioxidant, antimicrobial, and free radical scavenging potential of aerial parts of Periploca aphylla and Ricinus communis. ISRN Pharmacol doi:10.5402/2012/563267

6.Mustafa G, Anis E, Ahmed S, Anis I, Ahmed H, Malik A, Shahzad-ul-Hassan S \& Choudhary MI ( 2000). LupeneType Triterpenes from Periploca aphylla. J Nat Prod 63(6): 881-3.

7.Rauf A, Uddin G, Ali M, Muhammad N \& Gul S (2013). Phytochemical screening and antioxidant activity of Pakistani medicinal plants. Wud J Med Plant 2: 1-6.

8.Joseph BS, Kumbhare PH \& Kale MC (2013). Preliminary phytochemical screening of selected Medicinal Plants. Int Res J Sci \& Eng 1(2): 55-62.

9.Qureshi M, Mehjabeen, Jahan N, Muhammad S, Mohani N, Wazir A, Baig IA \& Ahmad M (2015). Evaluation of neuropharmacological, analgesic and anti-inflammatory effects of the extract of Centella asiatica (Gotu kola) in mice. Afr. J. Pharm. Pharmacol. 9(41): 995-1001.

10. Kasture VS, Deshmuk VK \& Chopde CT (2002). Anxiolytic and anticonvulsive activity of Sesbania grandiflora leaves in experimental animals. Phytother Res 16: 455-460.

11. Sakina MR \& Dandiya PC (1990). A psychopharmacological profile of
Centella asiatica extract. Fitoterapia 61: 291-296.

12. Sanchez-Mateo CC, Prado B \& Rabanal RM (2002). Antidepressant effects of the methanol extract of several Hypericum species from the Canary Islands. J Ethnopharmacol 79: 119-12

13. Najam R. Behavioral and memory boosting effects of intellan and cyanocobalamin in mice. Journal of Pharmacy and Nutrition Sciences. 2011; 1(1).

14. Porsolt RD, Le Pichon $M$ \& Jalfre $M$ (1977). Depression :A new animal model sensitive to antidepressant treatments,Nature 266: 730-732

15. Costa APR, Vieira C, Bohner LO, Silva CF, da Silva Santos EC, De Lima T CM \& Lino-de-Oliveira C (2013). A proposal for refining the forced swim test in Swiss mice. Progress in Neuro-Psychopharmacology and Biological Psychiatry 1(45): 150155.

16. Kafeel H, Sheikh D, Naqvi SB \& Ishaq H (2016). Antidepressant activity on methanolic extract of ananas comosus linn peel (MEACP) by using forced swim and tail suspension apparatus in mice. Sci Intl 28(3): 2525-2531

17. Chattopadhyay D, Arunachalam G, Mandal SC, Bhadra R \& Mandal AB (2003). CNS activity of the methanol extract of Mallotus peltatus (Geist) Muell Arg. leaf: an ethnomedicine of Onge. J Ethnopharm 85(1): 99-105.

18. Mehjabeen, Ahmad M, Jahan N, Rehman AB \& Muhammad S (2014). Antidiarrhoeal, Anti-inflammatory and analgesic activities of Symplocos racemesa roxb. Bark. Pak J Pharm Sci 27(6): 2221-2226

19. Verma A, Jana GK, Sen S, Chakraborty R, Sachan S \& Mishra A (2010). Pharmacological Evaluation of Saraca 
indica Leaves for central nervous system depressant activity in mice. $J$ Pharm Sci Res 2: 338- 343

20. Dolai N, Karmakar I, Kumar RB \& Haldar PK (2012). CNS depressant activity of Castanopsis indica leaves. Orien Phar Exp Med 12(2): 135-140

21. Riaz M, Zia-Ul-Haq M, Ur-Rahman N \& Ahmad M (2014). Neuropharmacological effects of methanolic extracts of Rubus fruticosus L. Turk J Med Sci 44(3): 454-460.

22. Kolawole OT, Makinde JM \& Olajide OA (2007). Central nervous depressant activity of Russelia equisetiformis. Niger J Physiol Sci 22: 59-63

23. Khatun H, Majumder R, Alam EK, Mamun A, Ibne J S \& Alam B (2014). Preliminary pharmacological activity of the methanolic extract of Premna integrifolia barks in rats. Avic $J$ Phytomed 4(3): 215-24

24. Bhattacharya SK \& Satyan KS (1997). Experimental methods for evaluation of psychotropic agents in rodents: Anti-anxiety agents. Indian J Exp Biol 35: $565-575$

25. Subarnas A, Tadano T, Nakahata N, Arai $\mathrm{Y}$, Kinemuchi $\mathrm{H}$, Oshima $\mathrm{Y}$, Kisara K \& Ohizumi Y (1993). A possible mechanism of antidepressant activity of beta-amyrin palmitate isolated from Lobelia inflata leaves in the forced swimming test. Life 52: 289-296

26. Jäger AK \& Saaby L (2011). Flavonoids and the CNS. Molecules 16(2): 14711485

27. Subedi NK, Rahman SM \& Akbar M A (2016). Analgesic and antipyretic activities of methanol extract and its fraction from the root of Schoenoplectus grossus. Evid-B Comp Alt $\quad$ Med doi.org/10.1155/2016/3820704

28. Shams-Ud-Doha KM, Al Mahmud Z, Bachar SC \& Qais N (2013). Antinociceptive, anti-inflammatory, antimicrobial and central nervous system depressant activities of ethanolic extract of leaves and roots of Gomphostemma parviflorum var. parviflorum wall. Pharmacog Res5(4): 233-240

29. Hunskaar S \& Hole K (1987). The formalin test in mice:dissociation between inflammatory and noninflammatory pain. Pain 30(1): 103114

30. Onasanwo SA \& Elegbe RA (2006). Anti-nociceptive and antiinflammatory properties of the leaf extracts of Hedranthera barteri in rats and mice. Afr J Biomed Res 9(2): 109 117 